\title{
Phospholemman, a Single-Span Membrane Protein, Is an Accessory Protein of Na,K-ATPase in Cerebellum and Choroid Plexus
}

\author{
Marina S. Feschenko, ${ }^{1}$ Claudia Donnet, ${ }^{1}$ Randall K. Wetzel, ${ }^{1}$ Natalya K. Asinovski, ${ }^{1}$ Larry R. Jones, ${ }^{2}$ and \\ Kathleen J. Sweadner ${ }^{1}$ \\ ${ }^{1}$ Laboratory of Membrane Biology, Neuroscience Center, Massachusetts General Hospital, Charlestown, Massachusetts 02129, and ${ }^{2}$ Krannert Institute of \\ Cardiology, Indiana University School of Medicine, Indianapolis, Indiana 46202
}

Phospholemman (FXYD1) is a homolog of the Na,K-ATPase $\gamma$ subunit (FXYD2), a small accessory protein that modulates ATPase activity. Here we show that phospholemman is highly expressed in selected structures in the CNS. It is most abundant in cerebellum, where it was detected in the molecular layer, in Purkinje neurons, and in axons traversing the granule cell layer. Phospholemman was particularly enriched in choroid plexus, the organ that secretes CSF in the ventricles, where it colocalized with Na,K-ATPase in the apical membrane. It was also enriched, with Na,K-ATPase, in certain tanycytes or ependymal cells of the ventricle wall. Two different experimental approaches demonstrated that phospholemman physically associated with the $\mathrm{Na}, \mathrm{K}$-ATPase in cerebellum and choroid plexus: the proteins copurified after detergent treatment and co-immunoprecipitated from solubilized crude membranes using either antiphospholemman or anti-Na,K-ATPase antibodies. Phospholemman antibodies precipitated all three Na,K-ATPase $\alpha$ subunit isoforms $(\alpha 1-\alpha 3)$ from cerebellum, indicating that the interaction is not specific to a particular $\alpha$ isoform and consistent with the presence of phospholemman in both neurons and glia. Antibodies against the C-terminal domain of phospholemman reduced Na,K-ATPase activity in vitro without effect on $\mathrm{Na}^{+}$affinity. At least two other FXYD family members have been detected in the CNS, suggesting that additional complexity of sodium pump regulation will be found.

Key words: Na,K-ATPase; phospholemman; FXYD; cerebellum; choroid plexus; Purkinje cell; Bergmann glia

\section{Introduction}

Phospholemman was first discovered as a readily phosphorylated protein in sarcolemma preparations from cardiac and skeletal muscle (Walaas et al., 1977; Jones et al., 1979). It is a 72-amino acid membrane-spanning protein with a 20 -amino acid cleavable signal sequence (Palmer et al., 1991). It is phosphorylated by protein kinases $\mathrm{A}$ and $\mathrm{C}$ in the heart in response to $\beta$ - and $\alpha$-adrenergic stimulation and in response to insulin in skeletal muscle (Presti et al., 1985a,b; Walaas et al., 1988, 1994). It is also a target of myotonic dystrophy and NIMA (Never in mitosis, gene A) kinases (Lu et al., 1994; Mounsey et al., 1999, 2000). This suggests that phospholemman has a role in signal transduction to integrate converging regulatory pathways. The link between phospholemman phosphorylation and its physiological role is not yet understood, however. Phospholemman induces ion and taurine permeability in oocytes and lipid bilayers (Moorman et al., 1992; Mounsey et al., 2000), but evidence is presented here that it is an accessory protein of Na,K-ATPase.

Phospholemman and the $\gamma$ subunit of the Na,K-ATPase are members of the FXYD gene family, which has seven members in mammals (Sweadner and Rael, 2000). Several FXYD proteins, the

\footnotetext{
Received Nov. 4, 2002; revised Dec. 20, 2002; accepted Dec. 20, 2002.

This work was supported by National Institutes of Health Grant R01-NS27653 (K.J.S.) and a Claflin distinguished scholar award (M.S.F.).

Correspondence should be addressed to Kathleen J. Sweadner, 149-6118, Massachusetts General Hospital, 149 13th Street, Charlestown, MA 02129. E-mail: sweadner@helix.mgh.harvard.edu.

Copyright $\odot 2003$ Society for Neuroscience $\quad 0270-6474 / 03 / 232161-09 \$ 15.00 / 0$
}

$\gamma$ subunit (FXYD2), PLMS (a dogfish shark FXYD family member), CHIF (FXYD4), and FXYD7, have been shown to associate with Na,K-ATPase (Mahmmoud et al., 2000; Therien and Blostein, 2000; Beguin et al., 2001, 2002), and while this manuscript was being revised, Crambert et al. (2002) independently showed that phospholemman interacts with $\mathrm{Na}, \mathrm{K}$-ATPase when expressed in Xenopus oocytes and in cardiac and skeletal muscle sarcolemma. The greatest sequence homology in the gene family is in a stretch of 35 amino acids that includes the transmembrane span, a portion of the intracellular domain, and a portion of the extracellular domain with the FXYD motif (PFxYD or Pro-Phe$\mathrm{x}$-Tyr-Asp) that identifies the family. Mutations in the PFxYD motif of $\gamma$ and CHIF were shown to disrupt interaction with the Na,K-ATPase (Beguin et al., 2001). When the FXYD family transmembrane span amino acid sequences are displayed on a helical wheel, they have invariant and nearly invariant residues all clustered on one face, with small and bulky residues aligned separately to form a ridge-and-groove structure (Sweadner and Rael, 2000). This is consistent with right-handed helix packing and suggests similar specificity in protein-protein interaction in the membrane, such as by interacting with the same site on Na,K-ATPase.

Phospholemman mRNA expression has been detected in the CNS (Chen et al., 1997; Bres et al., 2000; Bogaev et al., 2001), and phospholemman protein has been detected in cerebellar astrocytes cultured from 8-d-old rats (Moran et al., 2001). We set out to determine the distribution of phospholemman in the CNS and to test the hypothesis that it forms a complex with $\mathrm{Na}, \mathrm{K}$-ATPase. 
Parts of this paper were published previously in abstract form (Sweadner et al., 2001).

\section{Materials and Methods}

Immunofluorescence microscopy. Adult outbred rats were used for immunofluorescence microscopy. The methods for fixation, tissue sectioning, and double-label immunofluorescence have been described in detail elsewhere (Wetzel and Sweadner, 2001). The antibody used to detect phospholemman was an affinity-purified polyclonal rabbit antibody against the C terminus (now called PLM-C1; Moorman et al., 1992). This antibody also appropriately stains the sarcolemma of cardiac and skeletal muscle (results not shown). To detect $\mathrm{Na}, \mathrm{K}$-ATPase isoforms, we used monoclonal antibodies specific for rat Na,K-ATPase $\alpha 1$ subunit (McK1; Arystarkhova and Sweadner, 1996) and for $\alpha 2$ (McB2; Pacholczyk and Sweadner, 1997). A monoclonal antibody specific for $\alpha 3$ (XVI-F9G10; MA-319; Affinity BioReagents) was also used to stain cerebellum in experiments not shown. Confocal microscopy was performed with a Nikon (Melville, NY) TE300 fluorescence microscope equipped with a Bio-Rad (Hercules, CA) MRC 1024 scanning laser confocal system.

Membrane preparation and $\mathrm{Na}, \mathrm{K}$-ATPase purification. Similar procedures for membrane preparation were used for both cerebellum and choroid plexus. First, a crude microsome preparation was made by differential centrifugation. Tissue (bovine in most experiments) was homogenized in $0.315 \mathrm{~m}$ sucrose, $20 \mathrm{~mm}$ TrisCl, and $1 \mathrm{~mm}$ EDTA, pH 7.4 (SET), for cerebellum or (in $\mathrm{mm}$ ): 250 sucrose, 30 imidazole, and 1 EDTA, pH 7.3, for choroid plexus. Centrifugation was for $15 \mathrm{~min}$ at $5800 \times g$; pellets were collected, rehomogenized, and pelleted again; and the supernatants were combined and centrifuged for $1 \mathrm{hr}$ at $140,000 \times g$. The final pellets were collected and resuspended in SET. These fractions were used for immunoprecipitation experiments.

For partial purification of the Na,K-ATPase, the SDS-extraction procedure was used (Jørgensen, 1988). Bovine choroid plexus microsomes were suspended at $1.4 \mathrm{mg} / \mathrm{ml}$ in buffer containing (in mM): 2 ATP, 30 histidine, and 2 EDTA, pH 7.4, and SDS was added slowly with stirring from a stock solution to a final concentration of $0.56 \mathrm{mg} / \mathrm{ml}$. The mixture was allowed to stir for $30 \mathrm{~min}$ at room temperature and then loaded onto $36 \mathrm{ml} 7-30 \%$ sucrose gradients in (in mM): 20 Tris-Cl and 1 EDTA, $\mathrm{pH}$ 7.4. The gradients were centrifuged for $6 \mathrm{hr}$ at $27,000 \mathrm{rpm}$ in a Sorvall 627 swinging bucket rotor. Fractions were collected from a puncture at the bottom of the tube, diluted, and concentrated by centrifugation at $140,000 \times g$ for $30 \mathrm{~min}$. Canine or rat brain and choroid plexus tissue was used in some experiments with equivalent results.

Canine cardiac sarcolemma, used as a Western blot-positive control, was isolated as previously described (Jones, 1988). Rat kidney (renal medulla) Na,K-ATPase used as a control in activity measurements was purified by the Jørgensen SDS-extraction procedure above.

Immunoblot. SDS-gel electrophoresis was on Tricine gels made with $12.5 \%$ polyacrylamide (Schagger and von Jagow, 1987). To detect $\mathrm{Na}, \mathrm{K}-$ ATPase $\alpha$ subunits in blots of bovine tissue, anti-KETYY (a gift from Dr. J. Kyte, University of California, San Diego, CA) was used as a panspecific probe that detects the $\alpha 1-\alpha 3$ isoforms equally well. To detect each isoform individually, monoclonal antibody $6 \mathrm{~F}$ was used for $\alpha 1$ (Developmental Studies Hybridoma Bank); McB2 was used for $\alpha 2$; and XVIF9G10 was used for $\alpha 3$ (described above). In Figure 5, the $\alpha$ subunit was stained with K1, a rabbit antiserum against rat $\alpha 1$ cut from a gel (Sweadner and Gilkeson, 1985), and in Figure 6, $\alpha 5$, a monoclonal antibody that reacts with all three isoforms, was also used for either immunoprecipitation or staining of blots (Developmental Studies Hybridoma Bank). Affinity-purified antibodies against the $\mathrm{C}$ terminus of phospholemman, PLM-C1 (described above), or the extracellular portion, monoclonal antibody PLM-B8 (Moorman et al., 1995), were used to detect phospholemman.

Immunoprecipitation. To immunoprecipitate the Na,K-ATPase $\alpha$ subunit, we used either monoclonal antibody $6 \mathrm{H}$ (a gift from Dr. M. J. Caplan, Yale University Medical School, New Haven, CT) or monoclonal antibody $\alpha 5$ (described above). To immunoprecipitate phospholemman, the antibodies against either the $\mathrm{N}$ terminus (mouse monoclonal PLM-B8) or the C terminus (PLM-C1) were used (described above). Membranes from either choroid plexus or cerebellum (bovine) at $2 \mathrm{mg}$ of protein/ml were solubilized with $6 \mathrm{mg} / \mathrm{ml} n$-dodecyl octaethylene glycol monoether detergent $\left(\mathrm{C}_{12} \mathrm{E}_{8}\right.$; Calbiochem, La Jolla, CA) for $10 \mathrm{~min}$ at room temperature in a buffer containing (in $\mathrm{mm}$ ): $140 \mathrm{NaCl}, 25$ imidazole, and 1 EDTA, pH 7.3. The extract was diluted with an equal volume of detergent-free buffer, and insoluble material was sedimented by centrifugation for $30 \mathrm{~min}$ at $20,000 \times g$ at $4^{\circ} \mathrm{C}$. The pellet was checked for residual $\mathrm{Na}, \mathrm{K}-\mathrm{ATP}$ ase, which was very low. The supernatant was incubated with primary antibodies or control IgG $(1-2 \mu \mathrm{g} / \mathrm{ml})$ overnight at $4^{\circ} \mathrm{C}$ with rocking. The immune complexes were collected after $2 \mathrm{hr}$ of incubation with $40 \mu \mathrm{l}$ of secondary goat anti-rabbit or goat anti-mouse IgG antibodies covalently bound to agarose beads (Sigma, St. Louis, MO). Immunoprecipitates were collected by centrifugation at $9300 \times g$ for $10 \mathrm{~min}$ at $4^{\circ} \mathrm{C}$ and washed four times with solubilization buffer containing $0.05 \% \mathrm{C}_{12} \mathrm{E}_{8}$. After the final wash, the pellet was resuspended in $40 \mu \mathrm{l}$ of $1 \times$ electrophoresis sample buffer. Samples were incubated for 20 $\mathrm{min}$ at room temperature and centrifuged at $9300 \times \mathrm{g}$ for $10 \mathrm{~min}$. Supernatants were saved. Pellets were washed with an additional $20 \mu \mathrm{l}$ of electrophoresis sample buffer and centrifuged again. The supernatants were combined and heated for $10 \mathrm{~min}$ at $65^{\circ} \mathrm{C}$ to dissociate IgG before loading on the gel. The excess IgG heavy and light chains, a trace of undissociated IgG dimer, and some other contaminants originating in the antibody can be detected in the blots in Figures $6 \mathrm{~A}$ and 7.

Epitopes recognized by the PLM-C1 and PLM-B8 antibodies were mapped using cellulose-bound PepSpots (Jerini Bio Tools) by methods described previously (Kobayashi and Jones, 1999). The PepSpots sheet contained a series of immobilized 13 mer synthetic peptides, each overlapping by 11 residues, that covered the primary structure of canine phospholemman. PLM-C1, which was raised against a peptide with the sequence GTFRSSIRRLSTRRR, required the sequence FRSSIRRL for binding. PLM-B8, which is a monoclonal antibody raised against recombinant phospholemman expressed in Sf21 insect cells (Chen et al., 1998), required the $\mathrm{N}$-terminal sequence EHDPFTYDY for binding. Although this epitope contains the conserved FXYD motif, the antibody is quite specific. PLM-B8 does not recognize rat phospholemman, which differs only by a $\mathrm{P}$ for $\mathrm{H}$ substitution in the epitope and two amino acids (HT substituting for QS) immediately after it. We also did not see crossreactivity of PLM-B8 with the homologous sequence in FXYD2 (TENPFEYDY; results not shown).

Antibody-induced changes in Na,K-ATPase activity. SDS-purified bovine choroid plexus $\mathrm{Na}, \mathrm{K}$-ATPase was used to measure the effects of incubation with anti-phospholemman antibodies. The specific activity of the preparation (ouabain-sensitive ATPase activity) was $85 \mu \mathrm{mol}$ of ATP hydrolyzed $\cdot \mathrm{hr}^{-1} \cdot \mathrm{mg}$ of protein ${ }^{-1}$, measured in (in $\mathrm{mM}$ ): $130 \mathrm{NaCl}, 20$ $\mathrm{KCl}, 1$ ATP, 1 EDTA, 5 EGTA, $4 \mathrm{MgCl}_{2}$, and 30 Tris-HCl, pH 7.4. To assess the effect of antibodies on activity, the same medium was used but with either 5 or $100 \mathrm{~mm} \mathrm{NaCl}$. The hydrolysis of ATP was measured at $37^{\circ} \mathrm{C}$ by a colorimetric assay, and assays were performed with and without 2 mM ouabain. The antibodies used were PLM-C2, a newer rabbit antiserum that is equivalent to PLM-C1 (a gift from Dr. J. Cheung, Geisinger Medical Center; Song et al., 2002), PLM-B8 (described above), or control rabbit or mouse IgG as appropriate (Sigma). Before use, all antibodies were diluted with $4-5$ volumes of (in $\mathrm{mm}$ ): $50 \mathrm{NaCl}$ and 20 Tris-HCl, pH 7.5, concentrated with a centrifugal filter (Amicon, Beverly, MA; $30 \mathrm{kDa}$ cutoff), and washed three times with three volumes of the same buffer. This procedure controlled $\mathrm{NaCl}$ concentration and removed any phosphate buffer that would interfere with the assay, as well as Tris and glycine present in the affinity-purified antibody stock. Antibody protein was added in a 10 fold excess over sample protein.

For $\mathrm{Na}^{+}$affinity measurements with PLM-C2 antibodies or control IgG, the assay buffer contained the same basic constituents as the normal assay medium with $20 \mathrm{mM} \mathrm{K}^{+}$and different concentrations of $\mathrm{Na}^{+}$from 2.2 to $80 \mathrm{~mm}$. The ionic strength was kept constant by addition of choline $\mathrm{Cl}$ such that $\left[\mathrm{Na}^{+}\right]+\left[\mathrm{K}^{+}\right]+\left[\right.$choline $\left.{ }^{+}\right]=168 \mathrm{~mm}$. ATP hydrolysis was measured with $\left[\gamma^{-32} \mathrm{P}\right]$ ATP. Preincubation with antibodies was for $4 \mathrm{hr}$ at $4^{\circ} \mathrm{C}$ in (in $\mathrm{mm}$ ): $44 \mathrm{NaCl}$ and 17 Tris- $\mathrm{HCl}, \mathrm{pH}$ 7.5. This relatively low $\mathrm{NaCl}$ buffer was used because of the need to minimize the amount of $\mathrm{NaCl}$ added to the assay mixture during $\mathrm{Na}^{+}$affinity measurements. The final concentration of $\mathrm{Na}^{+}$contributed by the addition of enzyme preincubated with antibody or control IgG was $0.23 \mathrm{~mm}$. 


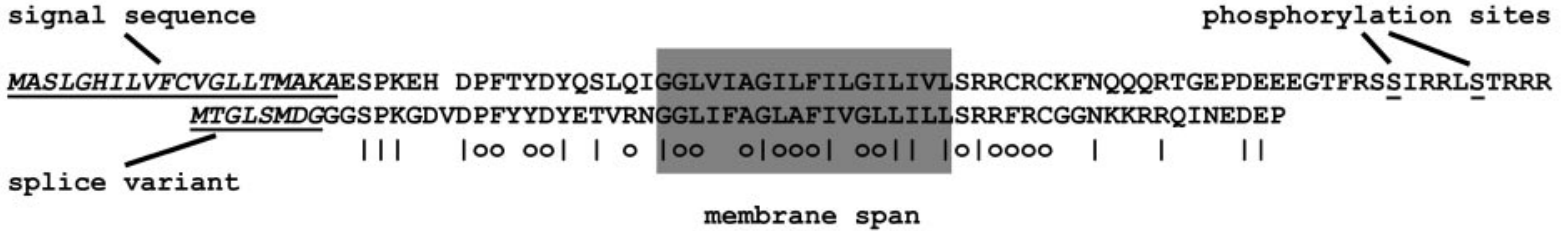

Figure 1. Alignment of phospholemman and the $\gamma$ subunit. The sequences of human phospholemman and $\gamma$ a are compared to display their similarity. One gap was allowed in phospholemman to allow alignment of three identical amino acids in the $\mathrm{N}$-terminal region. The leader sequence of phospholemman and the alternatively spliced $\mathrm{N}$ terminus of $\gamma$ are underlined and italicized. Following these two structures, the homology begins. As shown previously (Sweadner and Rael, 2000), there is a set of highly conserved amino acids that characterizes the entire FXYD family; these are marked with circles. Lines mark additional residues that are identical between phospholemman and $\gamma$. The known phosphorylation sites in the phospholemman C terminus are indicated; this segment has no counterpart in $\gamma$.

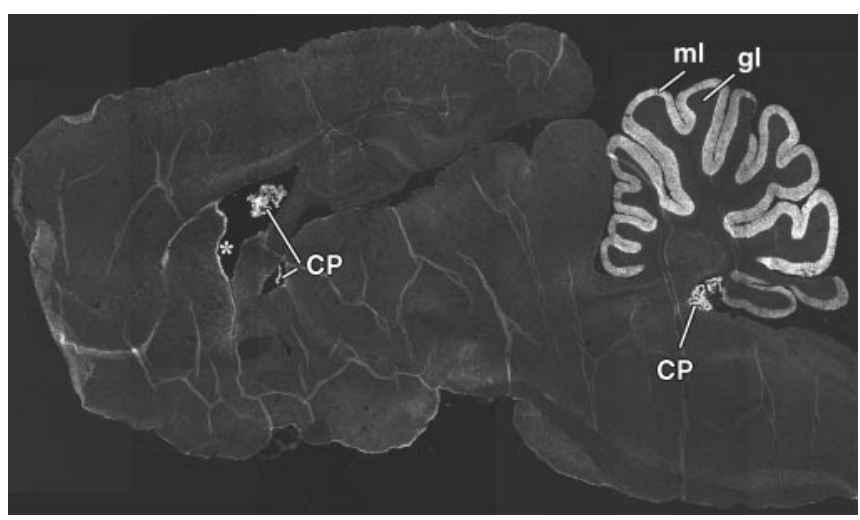

Figure 2. Phospholemman immunoreactivity in adult rat brain. A section of rat brain (without the olfactory bulb) stained with antibody against the (-terminal end of phospholemman, PLM-C1, is shown. The brightest immunoreactivity was in the cerebellar molecular layer $(\mathrm{ml})$ and in the choroid plexus $(C P)$, whereas the cerebellar granular layer $(g l)$ was almost unstained. Stained choroid plexus in (left to right) lateral, third, and fourth ventricles can be seen, as well as in presumptive tanycytes of the ependyma of the lateral ventricle (asterisk). Occasional folds in the section produced irregular brighter lines. The image is a montage of many individual confocal images.

\section{Results}

Figure 1 shows the aligned sequences of human phospholemman and $\mathrm{Na}, \mathrm{K}$-ATPase $\gamma$ subunit. For the portion extending from the end of the signal sequence of phospholemman to the end of the $\gamma$ sequence, the identity is $51 \%$, and the similarity is $64 \%$. For mouse, the identity is $48 \%$, and the similarity is $64 \%$, and for rat, the identity is $41 \%$, and the similarity is $61 \%$ (data not shown). The circles represent residues that are highly conserved in the entire FXYD family, and the dots represent additional residues that are identical between phospholemman and $\gamma$. This strong similarity led to the hypothesis that phospholemman associates with $\mathrm{Na}, \mathrm{K}$-ATPase.

\section{Phospholemman expression in brain}

Figure 2 shows the distribution of phospholemman immunoreactivity in the rat CNS. This montage of images from a rat brain sagittal section shows abundant immunoreactivity in the molecular layer of the cerebellum and in the choroid plexus in the lateral, third, and fourth ventricles. In addition, bright immunoreactivity was seen in cells of a portion of the ependymal lining of the lateral ventricle on its rostral surface posterior to the caudate putamen. Other areas showed much less immunoreactivity, although a detailed examination of all brain areas has not been performed.

Higher-magnification images of the cerebellar cortex doublelabeled for the $\alpha 1$ subunit isoform of Na,K-ATPase and phospholemman are shown in Figure $3 A-C$ and double-labeled for $\alpha 2$ and phospholemman in Figure 3D-F. Immunoreactivity for $\alpha 1$, $\alpha 2$, and $\alpha 3$ (results not shown) and phospholemman in the molecular layer was diffuse or fine-grained and was absent from the cytoplasm of the major Purkinje cell somas and dendrites, as expected for a membrane protein. Purkinje cell somas were completely unstained for $\alpha 1$ but exhibited surface ring staining for phospholemman. Purkinje cell somas were also usually unstained for $\alpha 2$ but were often in close contact with $\alpha 2$-stained astrocytes. The basket cell processes under the Purkinje cells were not visible with immunoreactivity for $\alpha 1$ or $\alpha 2$, but we confirmed that they are phospholemman-negative in other experiments using a double label with antibody to $\alpha 3$, which stains the basket cell processes well (results not shown) (for $\alpha 3$ distribution, see McGrail et al., 1991; Peng et al., 1997). In the granule cell layer, the only prominent immunoreactivity for phospholemman was in axons passing through. The $\alpha$ antibodies visualized other cell types in the granular layer; immunoreactivity for $\alpha 1$ highlighted the glomeruli (brightest), and each granule cell was ring-stained. The antibody to $\alpha 2$ stained the astrocytes, which send irregular processes between and around the granule cells. Phospholemman immunoreactivity with granule cells and glomeruli was below the level of detection, and the stain for granular layer astrocytes was very light. With this distribution, the most likely cells producing high levels of phospholemman in the cerebellum were the Purkinje neurons, the Bergmann glia (which are the specialized astrocytes of the molecular layer), or both. No other cell type has this distribution of arborization.

The choroid plexus is a simple cuboidal epithelium of polarized cells, and the Na,K-ATPase is located on the apical membrane, where its net outward transport of $\mathrm{Na}^{+}$drives the secretion of CSF (Wright, 1978). Figure $3 G-I$ shows that phospholemman colocalized with the $\alpha 1$ subunit of the $\mathrm{Na}, \mathrm{K}$ ATPase in the apical membrane. Similar colocalization of $\mathrm{Na}, \mathrm{K}$ ATPase and phospholemman was seen in bovine choroid plexus (results not shown). Figure $3 G-I$ also shows strong immunoreactivity for $\mathrm{Na}, \mathrm{K}$-ATPase and phospholemman in the apical membrane of some of the cells lining the ventricular wall. The distribution of $\mathrm{Na}, \mathrm{K}$-ATPase to the apical membrane predicts that these cells, like choroid plexus itself, may have a secretory function. On the basis of position, morphology, and apical specializations, it seems likely that these cells are tanycytes (Bruni, 1998).

The fact that phospholemman immunoreactivity in the cerebellar molecular layer appears to be brighter than $\alpha 1$ or $\alpha 2 \mathrm{im}$ munoreactivity is not evidence that there is an excess of phospholemman for several reasons: only one $\alpha$ isoform at a time was stained; the exposure intensity for the $\alpha$ subunits was adjusted to avoid overexposing the structures stained in the granular layer; and comparison of immunoreactivity of two antibodies is in any 

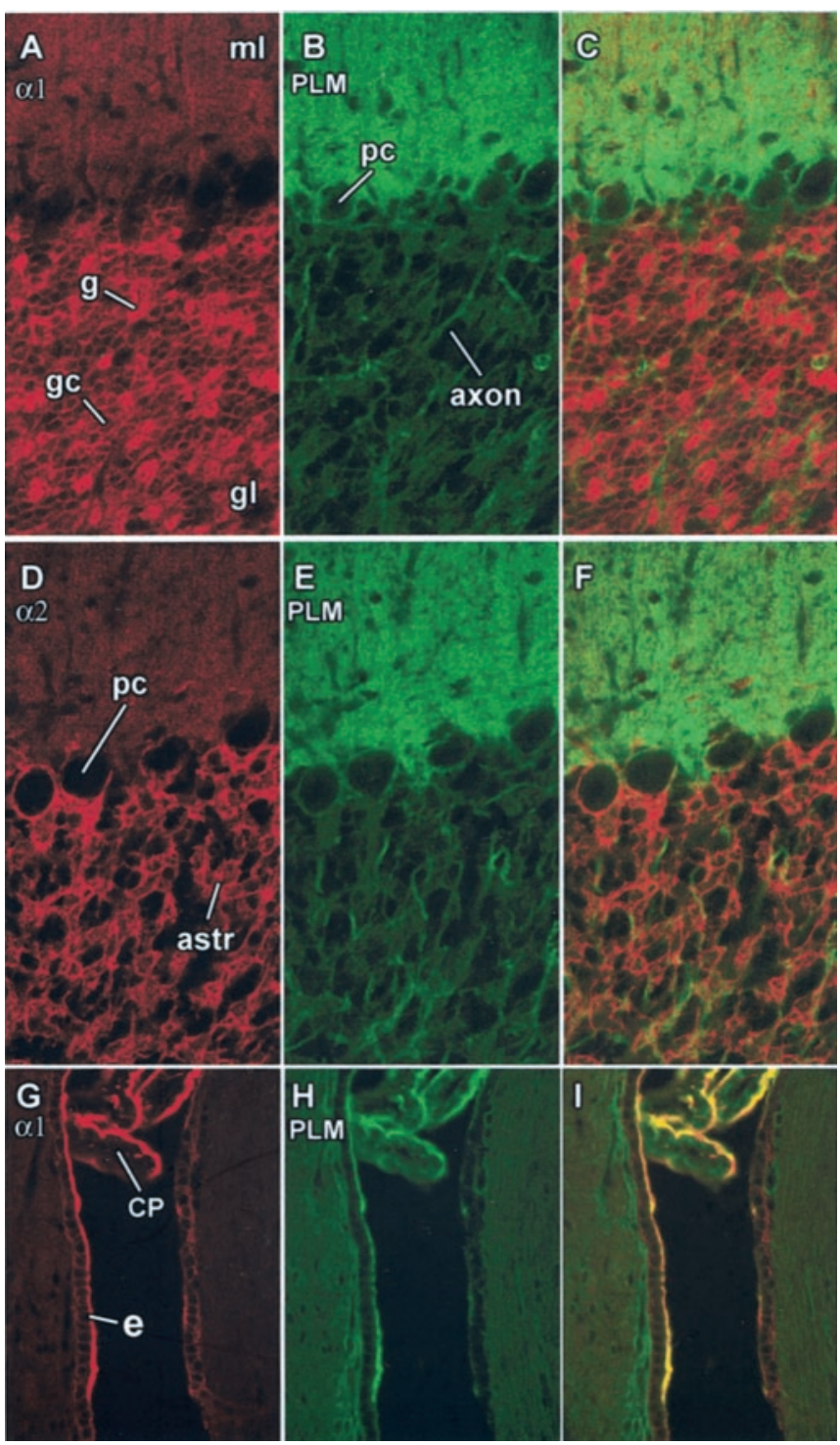

Figure 3. Phospholemman immunoreactivity in cerebellar cortex, choroid plexus, and ventricular wall. A-C, Cerebellar cortex double-labeled for phospholemman ( green), the $\alpha 1$ subunit of Na,K-ATPase (red), and the combined images. $\mathrm{ml}$, Molecular layer; $\mathrm{gl}$, granular layer. Immunoreactivity for $\alpha 1$ in the glomeruli $(g)$ in the granular layer was particularly bright and the granule cell bodies ( $g c$ ) were also stained, as was the molecular layer. Antibody to phospholemman stained the molecular layer and ring-stained Purkinje cells $(p c)$ and axons in the granular layer. D-F, Same structures double-labeled for the $\alpha 2$ isoform (red) and phospholemman ( green). Purkinje cells occasionally stained for $\alpha 2$, as reported previously (Peng et al., 1997); astrocytes in the granular layer (astr) were stained prominently for $\alpha 2$ but very lightly for phospholemman. G-I, Section of rat brain more lateral than that of Figure 2 double-labeled for Na,K-ATPase $\alpha 1$ (red) and phospholemman ( green). Both proteins were confined to the apical surface of the polarized epithelium of the choroid plexus $(C P)$, which lies here in a narrow ventricular space ventral to the chamber seen in Figure 2 . On the rostral surface of the ventricle, a cuboidal epithelium of ependymal cells, presumed tanycytes (e), is seen that was prominently stained for both $\mathrm{Na}$,K-ATPase and phospholemman at its apical surface.

event not quantitative. The difference in the proportion of immunoreactivity for $\alpha$ and phospholemman between molecular and granular layers, however, does imply that there is much less phospholemman in the granular layer relative to $\alpha$ subunits. Figure 4 shows that this was reflected in the ratio of phospholemman to $\alpha$ assessed with immunoblots. Bovine tissue was used instead of rat here because of the ease and yield of dissection. To detect all $\mathrm{Na}, \mathrm{K}-\mathrm{ATPase} \alpha$ isoforms equally, an antibody against a shared
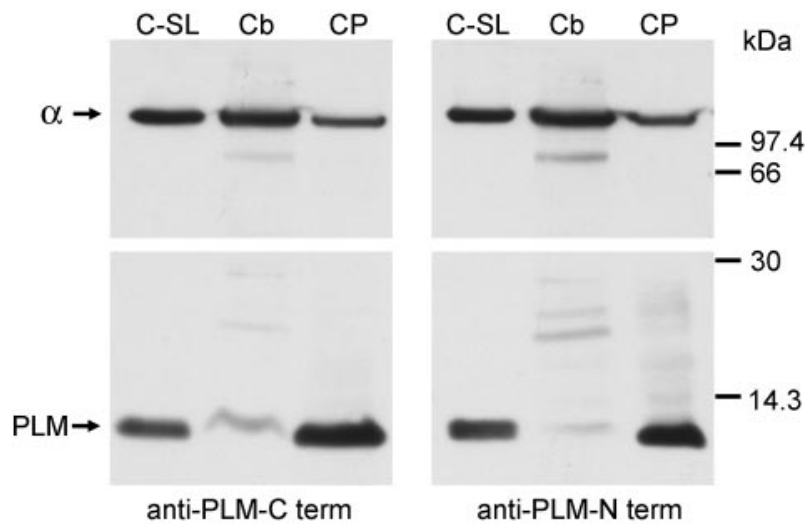

Figure 4. Ratio of phospholemman to Na,K-ATPase. Although the true ratio of phospholemman to the Na,K-ATPase $\alpha$ subunit cannot be determined by comparing the amount of immunoreactivity with two different antibodies, nonetheless, differences in the ratio between samples can be assessed. Here, two identical blots were prepared with samples of canine sarcolemma as a positive control for the antibodies (C-SL), cerebellar membranes $(C b)$, and choroid plexus membranes $(C P)$. The blots were cut in half. The top halves were stained for $\mathrm{Na}$,K-ATPase $\alpha$ subunit with the pan-specific KETYY antibody, and the bottom halves were stained with phospholemman antibodies against the $\mathrm{C}$ - and $\mathrm{N}$ termini, respectively. It can be seen that, relative to the amount of immunoreactivity for $\alpha$, there was much less phospholemman (PLM) in the cerebellum sample than the choroid plexus sample. Molecular weight markers are indicated. We have observed that in some gels, phospholemman runs at $15 \mathrm{kDa}$, as reported by others, but in these ( $12 \%$ acrylamide Tricine gels), it runs at $\sim 8 \mathrm{kDa}$ (compared with Bio-Rad Rainbow molecular weight markers), which is close to its predicted size.

determinant at the C terminus, KETYY, was used. Two different anti-phospholemman antibodies, against the $\mathrm{N}$ - and C-terminal ends of the protein, gave the same result. The ratio of phospholemman to $\alpha$ was much higher in membrane fractions isolated from choroid plexus than in membrane from whole cerebellar cortex and was if anything higher than the ratio seen in the cardiac sarcolemma fraction used as a control.

\section{Copurification of phospholemman with Na,K-ATPase}

The Na,K-ATPase can be purified from highly active tissue sources by a relatively simple technique that exploits its unusual resistance to denaturation by the strong detergent SDS (Jørgensen, 1988; Sweadner, 1988). In the presence of ATP or ADP to stabilize the enzyme at the active site, SDS (at ratios of up to 0.4 $\mathrm{mg} / \mathrm{mg}$ of protein) extracts contaminating proteins and leaves the Na,K-ATPase in the lipid bilayer. The membranes are separated from the extracted proteins and from free SDS by sedimentation on sucrose gradients. The $\gamma$ subunit of the kidney copurifies with $\mathrm{Na}, \mathrm{K}$-ATPase $\alpha$ and $\beta$ subunits by this method; therefore, it was tried with phospholemman-containing membranes from choroid plexus and brain. Figure 5 illustrates the result with bovine choroid plexus. Essentially all of the phospholemman cosedimented with the Na,K-ATPase in the gradient, with a peak at $\sim 18 \%$ sucrose, as shown by blots of gradient fractions stained for $\alpha$ and phospholemman. No free phospholemman fraction was detected. The same copurification of phospholemman with the Na,K-ATPase, without a free phospholemman fraction, was obtained with canine choroid plexus and with microsomes from whole rat brain (data not shown).

\section{Coimmunoprecipitation of phospholemman with Na,K-ATPase}

To determine whether phospholemman and Na,K-ATPase form a stable complex, immunoprecipitation was performed with $\mathrm{C}_{12} \mathrm{E}_{8}$ detergent-solubilized crude membranes obtained from ei- 


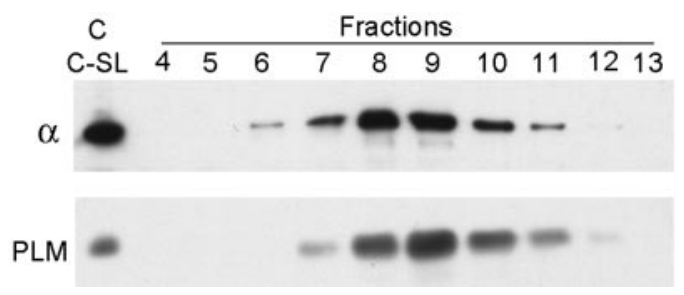

Figure 5. Copurification of phospholemman with Na,K-ATPase. Membranes from bovine choroid plexus were extracted with SDS and sedimented on a 7-30\% sucrose gradient. The bottom $8 \mathrm{ml}$ were discarded, and $142 \mathrm{ml}$ fractions were collected. Fraction samples were electrophoresed on a Tricine gel, and the blot was cut in half for staining for $\alpha$ (top; K1 antiserum) and phospholemman (bottom; PLM-C1). Essentially all of the phospholemman (PLM) sedimented into the gradient with the Na,K-ATPase. The final specific activity was 200 $\mu \mathrm{mol} \cdot \mathrm{mg}$ of protein ${ }^{-1} \cdot \mathrm{hr}^{-1}$ in this experiment. The control lane is a sample of canine sarcolemma (C-SL).
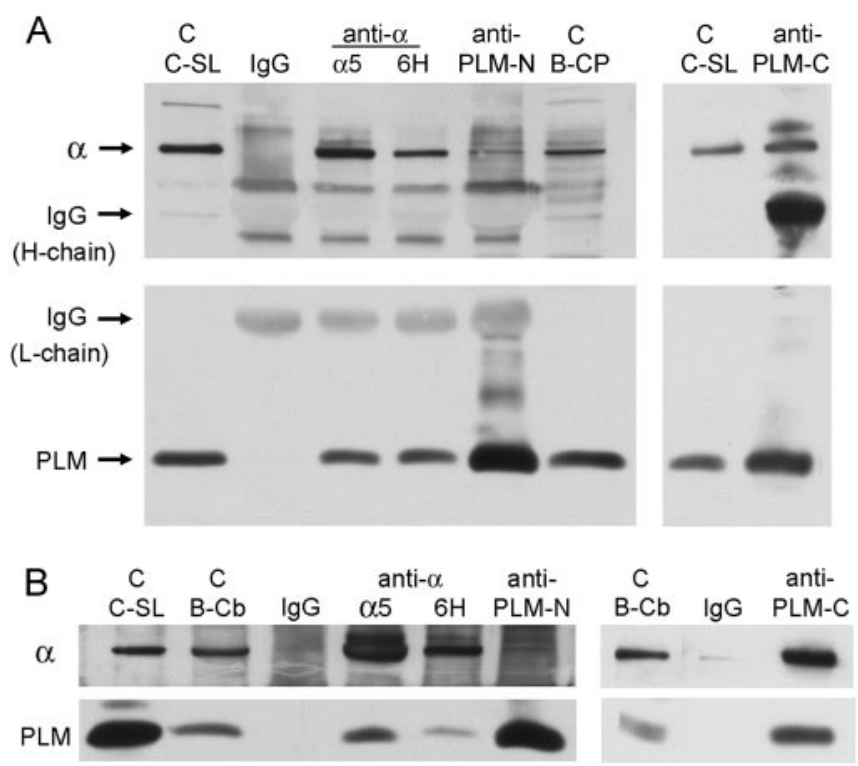

Figure 6. Coimmunoprecipitation of phospholemman with $\mathrm{Na}, \mathrm{K}$-ATPase. Canine sarcolemma samples were positive controls for the antibodies (C-SL). As indicated, samples were precipitated with normal IgG as a negative control, $\alpha 5$ or $6 \mathrm{H}$ antibodies against Na, K-ATPase $\alpha$ subunit, and anti-phospholemman N- and C-terminal antibodies (PLM-N, PLM-C). Immunoprecipitates and their controls were resolved by electrophoresis. Blots were cut in half for staining for Na,K-ATPase $\alpha$ (top; K1, $\alpha 5$, or anti-KETYY in different panels) and phospholemman (bottom; PLM-C1). A, Membranes from bovine choroid plexus. $B$, Membranes from bovine cerebellum. From both tissue sources, anti- $\alpha$ antibodies coprecipitated phospholemman (PLM), but phospholemman C-terminal antibody coprecipitated $\alpha$ well, and phospholemman N-terminal antibody coprecipitated it poorly.

ther choroid plexus or cerebellum. Figure 6 shows the excellent yield of solubilization under the conditions used and also shows controls in which nonimmune IgG was used for a mock precipitation. This control is important to show for immunoprecipitation, because some proteins sediment with the adsorbent, leading to false-positive signals. Two different Na,K-ATPase $\alpha$-specific antibodies were used, as well as two different phospholemman antibodies. Although the two $\alpha$-specific antibodies gave the same result, the two phospholemman antibodies showed differences that may be informative about the structure of the Na,K-ATPasephospholemman complex.

Figure $6 \mathrm{~A}$ shows that both anti- $\alpha$ antibodies were effective at coprecipitating phospholemman from bovine choroid plexus membranes, as was the antibody against the phospholemman $\mathrm{C}$ terminus (PLM-C1, the same antibody used for immunofluores-
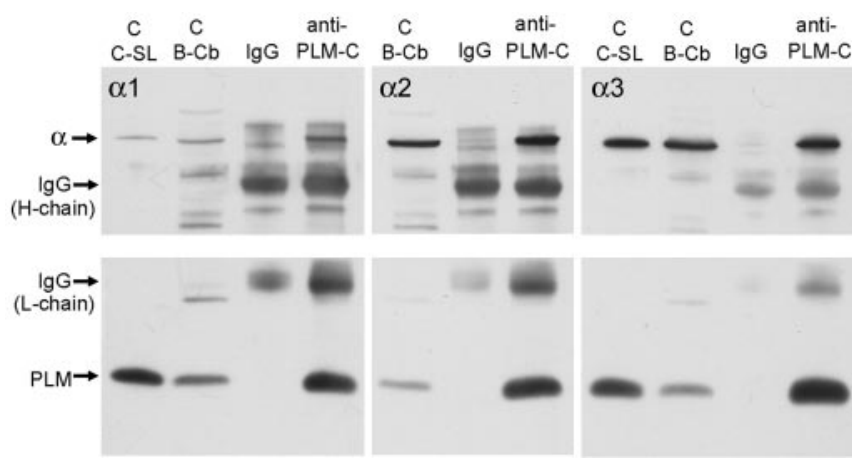

Figure 7. Coimmunoprecipitation of phospholemman with Na,K-ATPase $\alpha$ isoforms. Control lanes include both canine sarcolemma (C-SL) and samples of the bovine cerebellar membrane-starting material $(B-C b)$. Immunoprecipitation was performed with normal rabbit IgG as a negative control and the antibody against the C terminus of phospholemman (PLM-C). Three identical blots were prepared and cut in half. The bottom halves were all stained with the phospholemman antibody, but the top halves were stained with isoform-specific anti-Na, KATPase $\alpha$ subunit antibodies: antibody 6F for $\alpha 1$, McB2 for $\alpha 2$, and XVI-F9G10 for $\alpha 3$.

cence above). The PLM-B8 antibody against the phospholemman $\mathrm{N}$ terminus, however, precipitated phospholemman well but $\alpha$ only weakly. A similar result is seen in Figure $6 B$, where the membranes were from bovine cerebellum instead. Despite the presence of less phospholemman, the $\alpha$ antibodies and the antiC-terminal phospholemman antibody coprecipitated $\alpha$ and phospholemman very well, whereas the anti-N-terminal phospholemman antibody again precipitated phospholemman much better than $\alpha$. The anti-N-terminal antibody is against the conserved FXYD domain, and mutagenesis studies with other FXYD family members have suggested that FXYD is important for interaction with Na,K-ATPase (Beguin et al., 2001). The N terminus of phospholemman in sarcolemma is also very resistant to proteases, indicating its inaccessibility (Chen et al., 1998). We propose either that the anti-N-terminal antibody cannot bind to the extracellular portion of phospholemman when it is tightly associated with $\mathrm{Na}, \mathrm{K}$-ATPase, or that the antibody disrupts the phospholemman-Na,K-ATPase interaction in detergent. In contrast, the $\mathrm{C}$ terminus of phospholemman is not constrained in the same way. Because the $\mathrm{C}$ terminus has the phosphorylation sites, it should be accessible to approach by other proteins, including antibodies.

To determine which $\mathrm{Na}, \mathrm{K}$-ATPase $\alpha$ isoforms interact with phospholemman, immunoprecipitation from cerebellar membrane fractions was performed using the PLM-C1 antibody (Fig. 7). Each $\alpha$ isoform was detected with a well characterized isoform-specific monoclonal antibody. The result was that all three $\mathrm{Na}, \mathrm{K}-\mathrm{ATP}$ ase $\alpha$ isoforms coprecipitated. The lack of $\alpha$ in controls using normal rabbit IgG demonstrates that the precipitation was not an artifact. The conclusion is that phospholemman interaction with the Na,K-ATPase is not isoform-specific, and the implication is that phospholemman is expressed in both $\alpha 3$-containing neurons and $\alpha 2$-containing glia. This conclusion differs somewhat from that of Crambert et al. (2002), who reported that assembly with $\alpha 2$ was less efficient than with $\alpha 1$ in oocytes. The discrepancy may be attributable to a lack of $\beta 2$ in the oocytes, the most abundant partner of $\alpha 2$ in the brain.

Functional interaction of phospholemman with Na,K-ATPase To test the hypothesis that phospholemman regulates the activity or properties of the $\mathrm{Na}, \mathrm{K}$-ATPase, we incubated purified choroid plexus $\mathrm{Na}, \mathrm{K}$-ATPase (the preparation with the highest propor- 


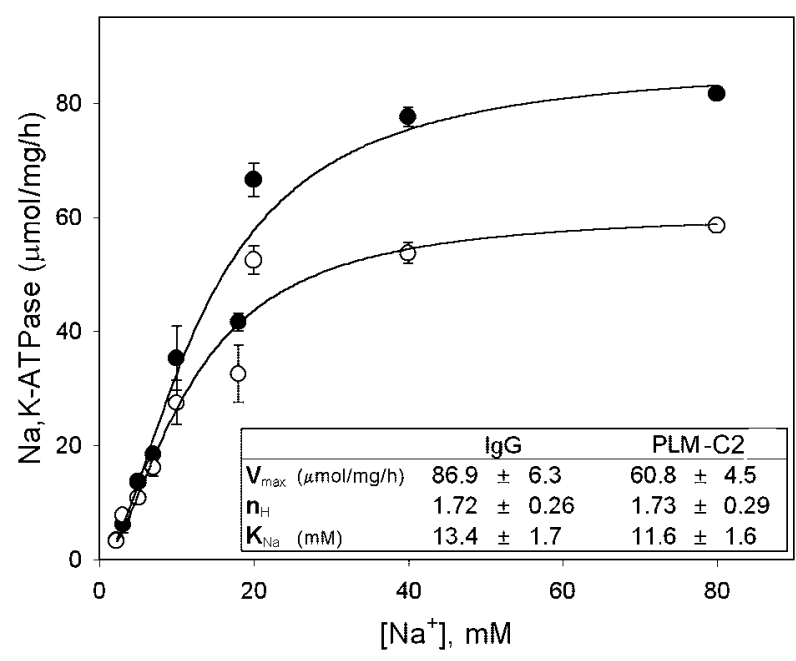

Figure 8. Effect of PLM-C2 antibody on Na,K-ATPase. Ouabain-sensitive Na,K-ATPase activity was determined as a function of $\mathrm{Na}^{+}$concentration after $4 \mathrm{hr}$ of preincubation at $4^{\circ} \mathrm{C}$ with either normal rabbit lgG ( filled circles) or PLM-C2 antibody (open circles). Inset, The following equation was fitted to the data: $v=V_{\max }\left[\mathrm{Na}^{+}\right]^{n \mathrm{HH}} /\left(\mathrm{K}_{\mathrm{Na}}{ }^{n \mathrm{H}}+\left[\mathrm{Na}^{+}\right]^{\mathrm{nH}}\right)$, where $V_{\text {max }}$ is the specific activity at a nonlimiting $\mathrm{Na}^{+}$concentration; $K_{\mathrm{Na}}$ is the $\mathrm{Na}^{+}$concentration giving half-maximal activity; and $n \mathrm{H}$ is the Hill coefficient. Best-fitting values for these parameters are given as mean \pm SEM, average of two experiments performed in duplicate.

Table 1. Anti-phospholemman antibody effects on Na,K-ATPase activity

\begin{tabular}{|c|c|c|c|c|}
\hline \multirow[b]{3}{*}{ Tissue } & \multicolumn{4}{|l|}{ Antibody } \\
\hline & PLM-C2 & & PLM-B8 & \\
\hline & $\begin{array}{l}\text { Na,K-ATPase activity } \\
\text { (\% of control) }\end{array}$ & $n$ & $\begin{array}{l}\text { Na,K-ATPase activity } \\
\text { (\% of control) }\end{array}$ & $n$ \\
\hline Rat kidney & $109 \pm 11$ & 4 & ND & \\
\hline Choroid plexus & $79.2 \pm 3.9$ & 13 & $107.7 \pm 7.0$ & 8 \\
\hline
\end{tabular}

$\mathrm{Na}, \mathrm{K}$-ATPase purified from rat kidney or bovine choroid plexus was preincubated with the antibodies shown or with control lgG, and then ouabain-sensitive ATP hydrolytic activity was measured. $n$, Number of independent determinations; ND, not determined. The specific activities for different choroid plexus Na,K-ATPase preparations used averaged $15.2 \pm 2.0 \mu \mathrm{mol} \cdot \mathrm{hr}^{-1} \cdot \mathrm{mg}$ of protein ${ }^{-1}$ (when measured at $5 \mathrm{~mm} \mathrm{Na}^{+}$) and $37.5 \mu \mathrm{mol} \cdot \mathrm{hr}^{-1} \cdot \mathrm{mg}$ of protein ${ }^{-1}$ (when measured at $100 \mathrm{~mm} \mathrm{Na}^{+}$). Because no differences between results at 5 or $100 \mathrm{~mm} \mathrm{Na}^{+}$were observed, the data were combined. A paired $t$ test was applied to the results for kidney ( $\gamma$ instead of PLM) compared with choroid plexus. For the antibody PLM-C2, the results were significant at $p=0.021(p<0.05)$.

tion of phospholemman) with anti-phospholemman antibodies. Similar experiments with antibodies to the Na,K-ATPase $\gamma$ subunit gave some of the first evidence for its functional interaction with the pump (Therien et al., 1997, 1999). PLM-C2 is an antibody directed against the C-terminal portion of phospholemman similar to PLM-C1. Figure 8 shows that PLM-C2, measured at a range of $\mathrm{Na}^{+}$concentrations in vitro, produced a significant decrease in activity without affecting the apparent affinity for $\mathrm{Na}^{+}$. Table 1 summarizes additional data. PLM-C2 showed an average $20 \%$ reduction of choroid plexus $\mathrm{Na}, \mathrm{K}-\mathrm{ATP}$ ase activity measured in multiple experiments with either 5 or $100 \mathrm{mM} \mathrm{NaCl}$, whereas it had no effect on kidney Na,K-ATPase, which has the $\gamma$ subunit instead of phospholemman. There was no inhibition of the ouabain-insensitive $\mathrm{Mg}^{2+}$-ATPase of either preparation. The PLM-B8 antibody directed to the N-terminal domain of phospholemman did not have any effect on activity, which may be attributable to an inability to bind its target if the N-terminal portion of phospholemman is engaged in interaction with the $\mathrm{Na}, \mathrm{K}-\mathrm{ATP}$ ase. We verified that phospholemman was not phosphorylated in the conditions of our experiments (data not shown).

\section{Discussion}

\section{FXYD family members as sodium pump regulators}

Phospholemman is the fifth FXYD family member to exhibit interaction with $\mathrm{Na}, \mathrm{K}$-ATPase. There are precedents for the regulation of other transport ATPases by small membrane-spanning accessory proteins. Phospholamban, a 52-amino acid protein not homologous to FXYD proteins, regulates the sarcoplasmic reticulum $\mathrm{Ca}^{2+}$-ATPase (SERCA2a) of the heart. It is phosphorylated by protein kinase $\mathrm{A}$ and mediates $\beta$-adrenergic stimulation of contractility by reversing the inhibitory effect it has on the affinity of SERCA for $\mathrm{Ca}^{2+}$ (Simmerman and Jones, 1998). Its homolog sarcolipin is expressed in skeletal muscle with a different isoform of SERCA (Odermatt et al., 1998). Yeast have small membrane proteins that regulate the plasma membrane ATPase (Navarre et al., 1994). Ion channels also have accessory proteins that modulate functional properties (Suessbrich and Busch, 1999). Thus regulation of ion transport via small membrane proteins is becoming an important theme.

Three lines of evidence presented here support the hypothesis that phospholemman interacts specifically with the $\mathrm{Na}, \mathrm{K}$ ATPase: the two proteins copurify after SDS-extraction; they coimmunoprecipitate with antibodies against either component; and an anti-phospholemman antibody reduces Na,K-ATPase activity. Crambert et al. (2002) observed coprecipitation of phospholemman with $\mathrm{Na}, \mathrm{K}-\mathrm{ATP}$ ase from cardiac membranes or oocytes, and in oocytes, phospholemman decreased the apparent affinity for $\mathrm{Na}^{+}$(and $\mathrm{K}^{+}$). Because we observed inhibition of activity without effect on $\mathrm{Na}^{+}$affinity, at first glance, these results may seem contradictory. The emerging evidence for functional effects of FXYD proteins on Na,K-ATPase is quite complex, however. Effects on ATP hydrolysis, $\mathrm{Na}^{+}$affinity, and other properties appear to be experimentally separable and sometimes subject to modulation. The bottom line is that FXYD proteins, now including phospholemman, can affect functional properties of the $\mathrm{Na}, \mathrm{K}-\mathrm{ATP}$ ase, fine tuning its properties.

The inhibitory effect of antibody suggests that phospholemman might be an enzyme activator. In similar experiments on the $\gamma$ subunit, antibodies against the $\mathrm{C}$ terminus reduced activity (Therien et al., 1997), decreased apparent affinity for ATP (Therien et al., 1999), and increased the $\mathrm{IC}_{50}$ for vanadate inhibition (an experimental test of the distribution between two principal enzyme conformations, E1 and E2; Pu et al., 2001). Apparent affinity for ATP was increased in $\gamma$ transfectants of human embryonic kidney 293 and HeLa cells. Most recently, truncation of the $\mathrm{C}$ terminus was shown to abrogate the effect of $\gamma$ on apparent affinity for ATP (Pu et al., 2002). Together, these and other data suggested that the anti- $\gamma$ antibody favored E2, antagonizing a normal tendency of $\gamma$ to favor E1.

These apparent activating effects were not the only effects of the $\gamma$ subunit, however. There were decreases in apparent affinity for $\mathrm{Na}^{+}, \mathrm{K}^{+}$, or both in enzyme partially purified from transfected mammalian cells (Arystarkhova et al., 1999, 2002; Pu et al., 2001, 2002) and in oocytes (Beguin et al., 1997, 2001). This should reduce activity in vivo, because the effects occur in the physiological range. Anti- $\gamma$ antibodies, however, did not interfere with the effect on $\mathrm{Na}^{+}$affinity, nor did truncation of the $\mathrm{C}$ or $\mathrm{N}$ terminus (Pu et al., 2002). For these reasons, the lack of effect of anti-phospholemman antibody on $\mathrm{Na}^{+}$affinity reported here does not necessarily contradict the reduction in $\mathrm{Na}^{+}$affinity reported in oocytes (Crambert et al., 2002). Modulation of ion affinity may require the central domain and not the $\mathrm{C}$ terminus.

Further complexities in FXYD protein effects are also known. 
The expression of $\gamma \mathrm{N}$-terminal splice variants, as well as posttranslational modifications, changed how the $\gamma$ subunit altered $\mathrm{Na}, \mathrm{K}-\mathrm{ATP}$ ase affinities for $\mathrm{Na}^{+}$and $\mathrm{K}^{+}$in NRK-52E cells (Arystarkhova et al., 2002) but not in HeLa cells (Pu et al., 2001). Thus different domains of $\gamma$ may be responsible for different effects, and the effects may be modified by factors specific to the cell type. Interestingly, CHIF (FXYD4) increased the affinity of $\mathrm{Na}, \mathrm{K}$ ATPase for $\mathrm{Na}^{+}$(the opposite of the effect of $\gamma$ and phospholemman; Beguin et al., 2001; Garty et al., 2002), whereas FXYD7 decreased $\mathrm{K}^{+}$affinity at the extracellular site (Beguin et al., 2002). These proteins are homologous to both $\gamma$ and phospholemman in the central domain, yet each has a subtly different effect on $\mathrm{Na}, \mathrm{K}-\mathrm{ATPa}$ e properties. There is wide sequence variation in the extracellular and intracellular domains, providing a further basis for different functional roles. Because of the complexity of $\mathrm{Na}, \mathrm{K}$ ATPase kinetics, it is going to take considerable effort to fully understand the properties of these proteins in regulating the sodium pump.

Phospholemman also presents the special problem that it has four potential phosphorylation sites in the cytoplasmic domain, which are expected to be important in regulating its properties. The FXYD protein found in shark, PLMS, reduced Na,K-ATPase activity, and its phosphorylation increased activity (Mahmmoud et al., 2000). Preliminary experiments on phospholemman phosphorylation in vitro produced both stimulatory and inhibitory effects, suggesting that it matters which sites are phosphorylated (our unpublished observations).

We have independent evidence that phospholemman may play a role as an activator of $\mathrm{Na}, \mathrm{K}-\mathrm{ATP}$ ase. The specific activity of $\mathrm{Na}, \mathrm{K}-\mathrm{ATP}$ ase in cardiac membranes of a phospholemman knock-out mouse was significantly lower than in its control (L. G. Jia, C. Donnet, R. C. Bogaev, R. J. Blatt, C. E. McKinney, K. H. Day, S. S. Berr, L. R. Jones, J. R. Moorman, K. J. Sweadner, and A. L. Tucker, unpublished results). This is consistent with the hypothesis that the PLM-C2 antibody acts as an interfering antibody that antagonizes a normal stimulatory effect of phospholemman.

\section{FXYD proteins in the CNS}

The association of phospholemman with Na,K-ATPase in choroid plexus is highly suggestive of a role in the regulation of CSF secretion. Secretion and Na,K-ATPase activity are both known to be regulated by hormones and transmitters through protein kinases (Fisone et al., 1995, 1998; Ellis et al., 2000). Given that there is uncertainty about the universality of the $\mathrm{Na}, \mathrm{K}$-ATPase protein kinase $\mathrm{C}$ site and the accessibility of the protein kinase A site, phospholemman could be the critical kinase target.

Phospholemman has a unique distribution in cerebellum. The stained axons passing through the granular layer were most likely axons of Purkinje cells, because the cell bodies were clearly labeled. Similar immunoreactivity has been seen for the $\mathrm{Na}, \mathrm{K}-\mathrm{ATPase} \alpha 3$ subunit (Peng et al., 1997), which is expressed in Purkinje neurons (Watts et al., 1991). Although climbing fibers cannot be ruled out, mossy fibers can be ruled out, because the glomeruli, which contain their club-like termini in the granular layer, were unstained. The possibility that the stained axons could be granule cell axons seems unlikely. This would require strict subcellular routing to axons and not somas or dendrites, which were unstained in the granular layer. Furthermore, the axons extended into the white matter (data not shown). If Purkinje neurons were the only phos- pholemman-containing cells, however, coimmunoprecipitation with $\alpha 2$ would not be expected, because that isoform is expressed mostly in astrocytes and Bergmann glia (Watts et al., 1991; Peng et al., 1997). Astrocytes in the granular layer did not stain for phospholemman, but the diffuse immunoreactivity in the molecular layer could be in the plasma membranes of Bergmann glia as easily as in those of Purkinje neurons, because the two are closely interdigitated. Immunoreactivities for $\mathrm{Na}, \mathrm{K}-\mathrm{ATPase}$ isoforms $\alpha 1-\alpha 3, \beta 1$, and $\beta 2$ all have a similar diffuse distribution in the molecular layer (McGrail et al., 1991; Cameron et al., 1994; Peng et al., 1997), which reflects the small size and intimate contact of neuronal and glial processes. Phospholemman has been detected in cultures of cerebellar astrocytes from postnatal rats (Moran et al., 2001), something we have confirmed (data not shown). They presented evidence that reduction of phospholemman expression reduced astrocyte volume-sensitive taurine release. However, Bres et al. (2000) detected phospholemman mRNA in neurons but not in the astrocytes of the ventral glia limitans of the supraoptic nucleus and concluded that phospholemman was not important for volume-sensitive taurine release there. More investigation is needed.

We can speculate that association with FXYD family member accessory proteins is a common theme for $\mathrm{Na}, \mathrm{K}$-ATPase modulation. If so, proteins other than phospholemman must play this role in other parts of the brain. mRNA for FXYD6, variously called phosphohippolin (without evidence yet for phosphorylation), phospholemman-like protein, or vascular endothelial cell-specific protein (GenBank accession number AB030908), has been detected by in situ hybridization in cells of the hippocampal pyramidal cell layer and the granular layer of the cerebellum (Saito et al., 2001; Yamaguchi et al., 2001). From Northern blots (Beguin et al., 2002) and the sources of expressed sequence tags (ESTs; Sweadner and Rael, 2000), FXYD7 is expressed almost exclusively in the CNS, and ESTs for FXYD3 (mammary tumor marker 8) and FXYD5 (related to ion channel) have also been obtained from CNS libraries, predicting the presence of as many as five FXYD family members. Combined with the three Na,K-ATPase $\alpha$ isoforms and three $\beta$ isoforms that are expressed in different brain cell types in different combinations of $\alpha$ and $\beta$ (McGrail et al., 1991; Watts et al., 1991; Cameron et al., 1994; Peng et al., 1997; Martin-Vasallo et al., 2000), the potential subunit diversity of the sodium pump is considerable. In our opinion, the physiological significance of $\mathrm{Na}, \mathrm{K}$-ATPase regulation in the CNS is much neglected.

\section{References}

Arystarkhova E, Sweadner KJ (1996) Isoform-specific monoclonal antibodies to Na-K-ATPase $\alpha$ subunits: evidence for a tissue-specific post-translational modification of the $\alpha$ subunit. J Biol Chem 271:23407-23417.

Arystarkhova E, Wetzel RK, Asinovski NK, Sweadner KJ (1999) The $\gamma$ subunit modulates $\mathrm{Na}^{+}$and $\mathrm{K}^{+}$affinity of the renal Na,K-ATPase. J Biol Chem 274:33183-33185.

Arystarkhova E, Donnet C, Asinovski NK, Sweadner KJ (2002) Differential regulation of renal $\mathrm{Na}, \mathrm{K}-\mathrm{ATP}$ ase by splice variants of the $\gamma$ subunit. J Biol Chem 277:10162-10172.

Beguin P, Wang X, Firsov D, Puoti A, Claeys D, Horisberger JD, Geering K (1997) The $\gamma$ subunit is a specific component of the Na,K-ATPase and modulates its transport function. EMBO J 16:4250-4260.

Beguin P, Crambert G, Guennoun S, Garty H, Horisberger J-D, Geering K (2001) CHIF, a member of the FXYD protein family, is a regulator of $\mathrm{Na}, \mathrm{K}-\mathrm{ATP}$ ase distinct from the $\gamma$ subunit. EMBO J 20:3993-4002. 
Beguin P, Crambert G, Monnet-Tschudi F, Uldry M, Horisberger J-D, Garty $\mathrm{H}$, Geering K (2002) FXYD7 is a brain-specific regulator of $\mathrm{Na}, \mathrm{K}$ ATPase $\alpha 1-\beta$ isozymes. EMBO J 21:3264-3273.

Bogaev RC, Jia L, Kobayashi YM, Palmer CJ, Mounsey JP, Moorman JR, Jones LR, Tucker A (2001) Gene structure and expression of phospholemman in mouse. Gene 271:69-79.

Bres V, Hurbin A, Duvoid A, Orcel H, Moos FC, Rabie A, Hussy N (2000) Pharmacological characterization of volume-sensitive, taurine permeable anion channels in rat supraoptic glial cells. Br J Pharmacol 130:1976-1982.

Bruni JE (1998) Ependymal development, proliferation, and functions: a review. Microsc Res Tech 41:2-13.

Cameron R, Klein L, Shyjan AW, Rakic P, Levenson R (1994) Neurons and astroglia express distinct subsets of $\mathrm{Na}, \mathrm{K}-\mathrm{ATPase}$ alpha and beta subunits. Mol Brain Res 21:333-343.

Chen L-SK, Lo CF, Numann R, Cuddy M (1997) Characterization of the human and rat phospholemman (PLM) cDNAs and localization of the human PLM gene to chromosome 19q13.1. Genomics 41:435-443.

Chen Z, Jones LR, O’Brian JJ, Moorman JR, Cala SE (1998) Structural domains in phospholemman: a possible role for the carboxyl terminus in channel inactivation. Circ Res 82:367-374.

Crambert G, Fuzesi M, Garty H, Karlish S, Geering K (2002) Phospholemman (FXYD1) associates with Na,K-ATPase and regulates its transport properties. Proc Natl Acad Sci USA 99:11476-11481.

Ellis DZ, Nathanson JA, Sweadner KJ (2000) Carbachol inhibits $\mathrm{Na}^{+}-\mathrm{K}^{+}$ATPase activity in choroid plexus via stimulation of the NO/cGMP pathway. Am J Physiol 279:C1685-C1693.

Fisone G, Snyder GL, Fryckstedt J, Caplan MJ, Aperia A, Greengard P (1995) $\mathrm{Na}, \mathrm{K}-\mathrm{ATPase}$ in the choroid plexus: regulation by serotonin/protein kinase C pathway. J Biol Chem 270:2427-2430.

Fisone G, Snyder GL, Aperia A, Greengard P (1998) Na,K-ATPase phosphorylation in the choroid plexus: synergistic regulation by serotonin/ protein kinase $\mathrm{C}$ and isoproterenol/cAMP-PK/PP-1 pathways. Mol Med 4:258-265.

Garty H, Lindzen M, Scanfano R, Aizman R, Fuzesi M, Goldshleger R, Farman N, Blostein R, Karlish SJD (2002) A functional interaction between CHIF and Na,K-ATPase: implication for regulation by FXYD proteins. Am J Physiol 283:F607-F615.

Jones LR (1988) Rapid preparation of canine cardiac sarcolemmal vesicles by sucrose flotation. Methods Enzymol 157:85-91.

Jones LR, Besch Jr HR, Fleming JW, McConnaughey MM, Watanabe AM (1979) Separation of vesicles of cardiac sarcolemma from vesicles of cardiac sarcoplasmic reticulum: comparative biochemical analysis of component activities. J Biol Chem 254:530-539.

Jørgensen PL (1988) Purification of $\mathrm{Na}^{+}, \mathrm{K}^{+}$-ATPase: enzyme sources, preparative problems, and preparation from mammalian kidney. Methods Enzymol 156:29-43.

Kobayashi YM, Jones LR (1999) Identification of triadin 1 as the predominant triadin isoform expressed in mammalian myocardium. J Biol Chem 274:28660-28668.

Lu KP, Kemp BE, Means AR (1994) Identification of substrate specificity determinants for the cell cycle-regulated NIMA protein kinase. J Biol Chem 269:6603-6607.

Mahmmoud YA, Vorum H, Cornelius F (2000) Identification of a phospholemman-like protein from shark rectal glands: evidence for indirect regulation of $\mathrm{Na}, \mathrm{K}-\mathrm{ATP}$ ase by protein kinase $\mathrm{C}$ via a novel member of the FXYDY family. J Biol Chem 275:35969-35977.

Martin-Vasallo P, Wetzel RK, Garcia-Segura LM, Molina-Holgado E, Arystarkhova E, Sweadner KJ (2000) Oligodendrocytes in brain and optic nerve express the $\beta 3$ subunit isoform of $\mathrm{Na}, \mathrm{K}-\mathrm{ATP}$ ase. Glia 31:206-218.

McGrail KM, Phillips JM, Sweadner KJ (1991) Immunofluorescent localization of three Na,K-ATPase isozymes in the rat central nervous system: both neurons and glia can express more than one Na,K-ATPase. J Neurosci 11:381-391.

Moorman JR, Palmer CJ, John JE, Durieux ME, Jones LR (1992) Phospholemman expression induces a hyperpolarization-activated chloride current in Xenopus oocytes. J Biol Chem 267:14551-14554.

Moorman JR, Ackerman SJ, Kowdley GC, Griffin MP, Mounsey JP, Chen Z, Cala SE, O’Brian JJ, Szabo G, Jones LR (1995) Unitary anion currents through phospholemman channel molecules. Nature 377:737-740.

Moran J, Morales-Mulia M, Pasantes-Morales H (2001) Reduction of phos- pholemman expression decreases osmosensitive taurine efflux in astrocytes. Biochim Biophys Acta 1538:313-320.

Mounsey JP, Lu KP, Patel MK, Chen ZH, Horne LT, John III JE, Means AR, Jones LR, Moorman JR (1999) Modulation of Xenopus oocyteexpressed phospholemman-induced ion currents by co-expression of protein kinases. Biochim Biophys Acta 1451:305-318.

Mounsey JP, John JEI, Helmke SM, Bush EW, Gilbert J, Roses A, Perryman MB, Jones LR, Moorman JR (2000) Phospholemman is a substrate for myotonic dystrophy protein kinase. J Biol Chem 275:23362-23367.

Navarre C, Catty P, Leterme S, Dietrich F, Goffeau A (1994) Two distinct genes encode small isoproteolipids affecting plasma membrane $\mathrm{H}^{+}$-ATPase activity of Saccharomyces cerevisiae. J Biol Chem 269:21262-21268.

Odermatt A, Becker S, Khanna VK, Kurzydlowski K, Leisner E, Pette D, MacLennan DH (1998) Sarcolipin regulates the activity of SERCA1, the fast-twitch skeletal muscle sarcoplasmic reticulum $\mathrm{Ca}^{2+}$-ATPase. J Biol Chem 273:12360-12369.

Pacholczyk T, Sweadner KJ (1997) Epitope and mimotope for an antibody to the Na,K-ATPase. Protein Sci 6:1537-1548.

Palmer CJ, Scott D, Jones LR (1991) Purification and complete sequence determination of the major plasma membrane substrate for cAMPdependent protein kinase and protein kinase $\mathrm{C}$ in myocardium. J Biol Chem 266:11126-11130.

Peng L, Martin-Vasallo P, Sweadner KJ (1997) Isoforms of Na,K-ATPase $\alpha$ and $\beta$ subunits in the rat cerebellum and in granule cell cultures. J Neurosci 17:3488-3502.

Presti CF, Jones LR, Lindemann JP (1985a) Isoproterenol-induced phosphorylation of a 15 kilodalton sarcolemmal protein in intact myocardium. J Biol Chem 260:3860-3867.

Presti CF, Scott BT, Jones LR (1985b) Identification of an endogenous protein kinase $\mathrm{C}$ activity and its intrinsic 15 -kilodalton substrate in purified canine cardiac sarcolemmal vesicles. J Biol Chem 260:13879-13889.

$\mathrm{Pu}$ HX, Cluzeaud F, Goldshleger R, Karlish SJD, Farman N, Blostein R (2001) Functional role and immunocytochemical localization of the $\gamma \mathrm{a}$ and $\gamma \mathrm{b}$ forms of the Na,K-ATPase $\gamma$ subunit. J Biol Chem 276:20370-20378.

Pu HX, Scanzano R, Blostein R (2002) Distinct regulatory effects of the $\mathrm{Na}, \mathrm{K}$-ATPase $\gamma$ subunit. J Biol Chem 277:20270-20276.

Saito S, Matoba R, Kato K, Matsubara K (2001) Expression of a novel member of the ATP1G1/PLM/MAT8 family, phospholemman-like protein (PLP) gene, in the developmental process of mouse cerebellum. Gene 279:149-155.

Schagger H, von Jagow G (1987) Tricine-sodium dodecyl sulfatepolyacrylamide gel electrophoresis for the separation of proteins in the range from 1 to $100 \mathrm{kDa}$. Anal Biochem 166:368-379.

Simmerman HKB, Jones LR (1998) Phospholamban: protein structure, mechanism of action, and role in cardiac function. Physiol Rev 78:921-947.

Song J, Zhang X-Q, Carl LL, Qureshi A, Rothblum LI, Cheung JY (2002) Overexpression of phospholemman alters contractility and $\left[\mathrm{Ca}^{2+}\right]$ transients in adult rat myocytes. Am J Physiol 283:H576-H583.

Suessbrich H, Busch AE (1999) The IKs channel: coassembly of IsK (minK) and KvLQT1 proteins. Rev Physiol Biochem Pharmacol 137:191-226.

Sweadner KJ (1988) Preparation of the alpha(+) isozyme of the $\mathrm{Na}^{+}, \mathrm{K}^{+}$ATPase from mammalian axolemma. Methods Enzymol 156:65-71.

Sweadner KJ, Gilkeson RC (1985) Two isozymes of the Na,K-ATPase have distinct antigenic determinants. J Biol Chem 260:9016-9022.

Sweadner KJ, Rael E (2000) The FXYD gene family of small ion transport regulators or channels: cDNA sequence, protein signature sequence, and expression. Genomics 68:41-56.

Sweadner KJ, Feschenko MS, Wetzel RK, Asinovski NK, Ellis DZ, Jones LR, Arystarkhova E (2001) Single-span membrane protein modulators of $\mathrm{Na}, \mathrm{K}-\mathrm{ATPase}$ : phospholemman association with $\mathrm{Na}, \mathrm{K}$-ATPase in neurons and choroid plexus. Soc Neurosci Abstr 27:505.15.

Therien AG, Goldshleger R, Karlish SJD, Blostein R (1997) Tissue-specific distribution and modulatory role of the $\gamma$ subunit of the Na,K-ATPase. J Biol Chem 272:32628 -32634.

Therien AG, Karlish SJD, Blostein R (1999) Expression and functional role of the $\gamma$ subunit of the $\mathrm{Na}, \mathrm{K}-\mathrm{ATP}$ ase in mammalian cells. J Biol Chem 274:12252-12256.

Therien AG, Blostein R (2000) Mechanisms of sodium pump regulation. Am J Physiol 279:C541-C566. 
Walaas O, Walaas E, Lystad E, Rye-Alertsen A, Horn RS, Fossum S (1977) A stimulatory effect of insulin on phosphorylation of a peptide in sarcolemma-enriched membrane preparation from rat skeletal muscle. FEBS Lett 80:417-422.

Walaas SI, Horn RS, Albert KA, Adler A, Walaas O (1988) Phosphorylation of multiple sites in a 15000 dalton proteolipid from rat skeletal muscle sarcolemma, catalyzed by adenosine $3^{\prime}, 5^{\prime}$-monophosphate-dependent and calcium/phospholipid-dependent protein kinases. Biochim Biophys Acta 968:127-137.

Walaas SI, Czernik AJ, Olstad OK, Sletten K, Walaas O (1994) Protein kinase C and cyclic AMP dependent protein kinase phosphorylates phospholemman, an insulin- and adrenergic-regulated membrane phosphoprotein, at specific sites in the carboxy terminal domain. Biochem J 304:635-640.
Watts AG, Sanchez-Watts G, Emanuel JR, Levenson R (1991) Cell-specific expression of mRNAs encoding $\mathrm{Na}^{+}, \mathrm{K}^{+}$-ATPase $\alpha$-and $\beta$-subunit isoforms within the rat central nervous system. Proc Natl Acad Sci USA 88:7425-7429.

Wetzel RK, Sweadner KJ (2001) Immunocytochemical localization of the $\mathrm{Na}, \mathrm{K}$-ATPase $\alpha$ and $\gamma$ subunits in the rat kidney. Am J Physiol 281:F531-F545.

Wright EM (1978) Transport processes in the formation of the cerebrospinal fluid. Rev Physiol Pharmacol 83:1-34.

Yamaguchi F, Yamaguchi K, Tai Y, Sugimoto K, Tokuda M (2001) Molecular cloning and characterization of a novel phospholemman-like protein from rat hippocampus. Mol Brain Res 86:189-192. 